\title{
Extraabdominal Fibromatosis
}

National Cancer Institute

\section{Source}

National Cancer Institute. Extraabdominal Fibromatosis. NCI Thesaurus. Code C6489.

An insidious poorly circumscribed neoplasm arising from the soft tissues outside the abdomen. It is characterized by the presence of elong ated spindle-shaped fibroblasts, vascular collagenous stroma formation, and an infiltrative growth pattern. 